\title{
Bacteriological evaluation of packaged bottled water sold at J aipur city and its public health significance
}

\author{
Rakhi Gangil, Ruchi Tripathi, Anil Patyal, Pankaj Dutta and K.N. Mathur
}

Department of Veterinary Microbiology

Apollo College of Veterinary Medicine, Agra Road, Jamdoli, Jaipur (Rajasthan) - 302031, India

Corresponding author: Rakhi Gangil, email:rgangil@gmail.com

Received: 09-04-2012, Accepted: 24-05-2012, Published online: 05-11-2012

\section{How to cite this article:}

Gangil R, Tripathi R, Patyal A, Dutta P and Mathur KN (2013) Bacteriological evaluation of packaged bottled water sold at J aipur city and its public health significance, Vet World 6(1):27-30. doi: 10.5455/vetworld.2013.27-30

\begin{abstract}
Aim: The study was carried out to investigate the microbiological quality of packaged drinking water marketed in Jaipur city.

Material and Methods: In the present study 'twenty' drinking water samples (15 water bottles and 5 sachets) of different brands purchased randomly, were evaluated to access the water quality on the basis of different bacteriological parameters.

Result: Out of twenty, 50\% samples were found unsatisfactory in standard plate count. Psychrophillic, coliforms, E. coli and staphylococcal counts revealed that $25 \%, 45 \%, 20 \%$, and $5 \%$ samples respectively were found unfit for human consumption as per Bureau of Indian Standards (BIS) of drinking water. On the basis of results of overall microbiological assessment $55 \%$ of samples proved to be unfit for consumption. All brands of water sachet (100\%) had high coliforms count which indicates faecal contamination. Amongst those sachets two brands (40\%) had presence of E. coli and all the sachet water brands fell below drinking water standards while out of fifteen brands of bottled water 6 samples contained higher microbiological value hence unfit for human consumption.

Conclusion: Local brands of packaged drinking water were found unfit for human condumption. So it is suggested that government should intensify the efforts in the monitoring of activities in this rapidly expanding industry with a view to supply potable and wholesome water to the public.
\end{abstract}

Key words: bacteriological quality, bottled, mineral water, public health

\section{I ntroduction}

Water is one of the indispensable resources for the continued existence of all living things including man. The provision of an adequate supply of a safe drinking water was one of the eight components of primary health care identified by the international conference on primary health care in 1978. A clean and treated water supply to each house may be the norm in developed countries, but in developing countries, access to both clean water and sanitation are not the rule, and waterborne infections are common. Two and a half billion people have no access to improved sanitation, and more than 1.5 million children die each year from diarrheal diseases. According to the WHO, the mortality of water associated diseases exceeds 5 million people per year [1].Water problem is a serious problem in India as about $70 \%$ of surface water resources are being contaminated by biological toxic, organic and inorganic pollutants [2]. Much of ill health which affects humanity primarily in developing countries can be traced due to lack of safe and wholesome water supply. As water is a primary necessity of life, abundant and widely distributed in nature but on other hand it is good solvent so get polluted easily. Rapid urbanization, industrialization and increase in human and animal population densities had a remarkable impact on global ecology and environmental quality. So safety of water has become a matter of great concern. In recent time demand for packaged water is growing day by day around the world and India is no exception to it. The usage of bottled water in the world includes mainly North America (30\%), Europe (29\%), Asia (27\%) and other part of world (14\%) [3].

In India, there is an astronomical increase in the consumption of packaged waters especially bottled and sachet drinking water. The increased demand for drinking water products is attributed largely to factors such as inadequate or non availability of reliable, safe municipal water in urban areas.

The association between water and disease has been known for long. The first authenticated report of water borne disease from broad street water pump, London was given by John snow. Since then water borne disease outbreaks in human communities has been regularly reported from different parts of world including India. In India water borne outbreaks are common and few get reported. Near Vellore an outbreak was reported and 69 persons affected [4]. The higher incidence of diarrhoea is always associated with poor quality of drinking water [5].

In a study, the presence of presumptive coliforms 
Table-1. Percentage of positive samples for bacteriological parameter of packaged drinking water.

\begin{tabular}{llcc}
\hline S.No. & Bacteriological Parameter & $\begin{array}{c}\text { Frequency of samples have higher microbiological value } \\
\mathbf{n = 2 0} \text { (15 bottle +5 sachet) }\end{array}$ & Percentage value \\
\hline 1. & Standard Plate count & 10 & $50 \%$ \\
2. & Psychrophillic count & 5 & $25 \%$ \\
3. & Coliforms count & 9 & $45 \%$ \\
4. & E.Coli & 4 & $20 \%$ \\
5. & Staphylococcus & 1 & $5 \%$ \\
\hline
\end{tabular}

was reported in 10 percent samples collected from the bottled water manufactured by some brands [6]. Although bacteria may be present in bottled waters at low concentrations they are usually harmless, and outbreaks of human illness associated with bottled water are infrequent compared to those linked to tap water [7].

Day by day increase in the sale and indiscriminate consumption of packaged drinking waters in Jaipur city is of public health significance. The present study was conducted to evaluate the bacteriological quality of some packaged drinking water available in Jaipur (Rajasthan).

\section{Materials and Methods}

During study a total of 20 samples ( 15 bottled and 5 sachet-packed) of different brands of packaged mineral water were collected. All samples were purchased randomly from local market and street vendors of Jaipur city. They were transported in refrigerated conditions to the laboratory of the Department of Microbiology, Apollo College of Veterinary Medicine Agra Road, Jaipur and were examined in the lab within 4-6 hrs. of collection.

All the samples of mineral water were subjected to their bacteriological quality on the bases of standard plate count [8], psychrophillic count [9], Coliform count [8], Escherichia coli count [8] and staphylococcal count [10].

Ten $\mathrm{ml}$ of each water sample was diluted in $90 \mathrm{ml}$ sterile normal saline solution (NSS). Ten fold dilutions up to the $10^{-6}$ were prepared in test tubes from collected sample for using various bacteriological evaluations in bottled and sachet-packed water. One $\mathrm{ml}$ of each dilution was inoculated in to the plate count agar (Himedia) using pour plate technique to estimate total viable count (TVC). MacConkey agar and eosin methylene blue (EMB) agar (Hi-media) were used for isolation of E.coli, Total coliforms were estimated by using the 5-tube most probable number (MPN) method and Mannitol Salt Agar (MSA) (Hi-media) used as a selective media for staphylococcus spp.

\section{Results and Discussion}

Microbial evaluation of all water samples revealed that, out of twenty, $50 \%$ samples were found satisfactory in standard plate count. On the other hand, psychrophillic, coliforms, E.coli and staphylococcal counts revealed that $25 \%, 45 \%, 20 \%$, and $5 \%$ samples respectively were found unfit for human consumption as per Bureau of Indian Standards (BIS) for drinking water. (Table-1)
On the basis of results of overall bacteriological assessment, $45 \%$ of samples proved to be fit for consumption, while $55 \%$ samples had higher bacteriological values than BIS. Only $20 \%$ samples of bottled were found fit for consumption in Bikaner [11]. Fourty percent samples of bottled and sachet waters were failed to meet microbial quality standards, hawked in Ilorin metropolis [12]. According to World Health Organization, a high SPC concentration is itself present a risk to human health. SPC alone used as good indicators of the overall quality of production $[13,14]$. Therefore it is used in assessing the cleanliness of the different brands of bottle and sachet drinking waters sold in the selected areas of study.

In present study, psychrophilic count was unsatisfactory in $25 \%$ samples, while high range $(80 \%)$ of psychrophillic count were reported previously [11]; it must be due to presence of organic matter and availability of low temperature [15].

In present study, 45\% samples showed the presence of coliform while in Dhaka [16], in Lebanon [17], in Tehran [18], in Bikaner [11], in Fiji [19] and in Ethopia [20] reported the $31.11 \%, 18.8 \%, 14.28 \%$, $10 \%, 10 \%, 7 \%$, and $7.41 \%$ of coliform contamination of bottled water samples in their studies respectively. In contrast to above studies, results of another studies on bottled water around the world like, negative growth for coliforms or any microbial contamination in all bottled drinking water samples [21-23].

All brands of water sachet had high coliform count and two showed presence of E. coli. In other similar studies around the world like, in south east Nigeria [24], in western Nigeria [14], and in north eastern Nigeria [25] reported the presence of E. coli in $36 \%, 2.2 \%$ and $5 \%$ of total water sachet samples respectively. A study also showed the presence of faecal coliform and E. coli in sachet water from Nigeria [26].

These results show high faecal contamination in sachet water than bottled water. All the sachet water brands fell below drinking water standards. In a study of packaged drinking waters in Ibadan-Nigeria in which larger proportions of sachet water were found to show positive coliform counts compared to bottled waters [27]. In other study also reported the presence of E.coli by bacteriological analysis of the sachet drinking water samples [28].

Out of fifteen brands of bottled water 6 samples contained higher microbiological value hence unfit for consumption. It seems that the organism has survived in water for pretty long time because the bottled water 
kept under chilled conditions. Such contaminated water also leads to gastrointestinal diseases [29] and also responsible for food poisoning outbreaks. The carriage rate of E.coli and staphylococcus organism were found to be $20 \%$ and $5 \%$ respectively which support the findings of Uravashi et al., [11].

The absence of faecal indicator bacteria in most brands of bottled drinking water could be attributed to better hygienic practices observed in the industry compared to the sachet water producing industry. These include use of protective sealed caps on bottles, improved and hygienic filling system and use of nonreturnable plastic containers.

The microbial contaminations of packaged drinking water could be influenced by factors such as their raw water source, treatment process employed and hygienic practices observed in production [30]. Most sachet water manufacturers are observed to utilize well water or at best shallow, contaminated boreholes and municipal tap water as raw water source. Well water is usually contaminated by surface waters especially during the rainy season and inadequate attention paid to the environmental sanitary qualities of these wells. Wild animals and birds may also constitute natural sources of zoonotic pathogens contaminating surface and well water.

Ineffectiveness or malfunctioning of the treatment process employed could also result in the presence of coliform bacteria in the samples of water. According to Edberg [31] no treatment process or method used in mass production of drinking water yields a sterile product; it only produces a safe product devoid of pathogenic organisms. Appropriate treatment processes should therefore be utilised for production of quality and safe packaged drinking waters. Inadequate sanitation and unhygienic practices account for the major source of microbial contamination of any potable water [32]. High demand for packaged water for various occasions has led to springing up of small scale entrepreneurs who engage in production of packaged waters without due regard to hygienic practices in the production processes. The implication of this is lack of guarantee that the products will meet set standards for drinking water quality. In the bottled water industry, some bottlers have their bottles arriving at the factory without caps in cardboard boxes and these were always not properly washed or rinsed before being filled. This results in microbial contamination of the emerging product.

In this study, the microbiological analysis of bottled and sachet drinking water sold in the Jaipur city revealed the presence of SPC, total coliforms, E. coli, staphylococcal count in higher concentrations than those prescribed by WHO [33] and BIS recommendations and guidelines that make the products unfit for human consumption. The safety of bottled and sachet drinking water should be ensured through comprehensive regulatory programs at both the central and state levels before its release for public use.

\section{Conclusion}

Local brands of packaged drinking water were found unfit for human condumption. So it is suggested that government should intensify the efforts in the monitoring of activities in this rapidly expanding industry with a view to supply potable and wholesome water to the public.

\section{Author's contribution}

RG, RT and AP participated in the preparation of experimental design and the facilities of the research. RT and RG collected samples and send them to laboratory for identification. RG, RT, AP and PD involved in the bacteriological evaluation, analysed the data. RG, AP and KNM drafted and revised the manuscript. All the authors read and approved the final manuscript.

\section{Acknowledgements}

The authors are thankful to Dean, Apollo College of Veterinary Medicine, Jaipur for providing facility for present work.

\section{Competing interests}

Authors declare that they have no competing interests.

\section{References}

1. Cabral, J. P. S. (2010). Water Microbiology: Bacterial Pathogens and Water. Int. J. Environ. Res. Public Health, 7: 3657-3703.

2. Sudhakar, M.R. and Manatha, P. (2004). Water quality in sustainable water management. Current science 87:942-947.

3. Beverage Marketing Corporation of New York. 2010. Available at http://www.beveragemarketing.com/ globalbottledwater.doc. (Last access on 4th October, 2010).

4. Pai, M., Kang, G., Ramakrishna, B.S., Venkataraman, A. and Muliyil, J. (1997). An Epidemic of diarrhoea in south India caused by enteroaggregative E. coli. Indian J. Med. Res., 106: 7-12.

5. Bandyopadhyay, S., Banerjee, K., Khanna, K.K., Sharma, R.S. and Verghese, T. (1992). Drinking water quality and diarrhoea in Delhi. J. Com. Dis., 24: 156-158.

6. Reddy, Saraswathi, P.M.D., Rasheed, A. and Sharma, S. (2000). Microbiological analysis of bottled water. Indian J. Med. Microbiol., 18: 72-76.

7. Scientific Committee of the FSAI (2009). The consumption of bottled water containing certain bacteria or groups of bacteria and the implications for public health Available at: www.fsai.ie/WorkArea/DownloadAsset.aspx ?id=9286.

8. ISI (1981). Method of sampling and microbiological examination of water. Bureau of Indian Standards, New Delhi. IS: 1622-1981.

9. APHA (1955) Standard methods for the examination of water and industrial waste. Americam Public Health Association, $10^{\text {th }}$ ed., New York.

10. Chapman, G.H. (1946). A single culture media for selective isolation of plasma coagulating staphylococci and for improved testing for the chromogenesis, plasma coagulation, mannitol fermentation and store reaction. J. Bact., 51: 409.

11. Uravashi, Dukwal, V., Goyal, M. and Purohit, S.K. (2004). Physical, chemical and microbiological analysis of bottled water. J. Vet. Publ. Hlth., 2: 67-69.

12. Olayemi, A.B. (1999). Microbial potability of bottled and packaged drinking waters hawked in Ilorin metropolis. Int. J. Environ. Health Res., 9(3): 245-248.

13. Ferreira, A.C., Morais, P.V., Gomes, C. And Da Costa, M.S. (1994). Alterations intotal bacteria, iodonitrophenyl- 
tetrazolium (INT) positive bacteria and heterotrophic plate counts of bottled mineral water. Can. J. Microbiol., 40: 7277.

14. Olaoye, O.A. and Onilude, A.A. (2009). Assessment of microbiological quality of sachet-packaged drinking water in Western Nigeria and its public health significance. Public Health, 123(11):729-734.

15. Lunder, T. and Brenne, F. (1996). Factor in the farm production affection bacterial content in raw milk. Norwegian dairies, Norway. Symposium on Bacterilogical quality of raw milk, Wolfpassing, Austria, 1996, 103-107.

16. Majumder, A. K., Islam, K. M. N., Nite, R. N. and Noor, R. (2011). Evaluation of Microbiological Quality of Commercially Available Bottled Water in the City of Dhaka, Bangladesh. Stamford Journal of Microbiology, 1(1): 24-30.

17. Lucy, A. S. (2010). Quality assessment of various bottled waters marketed in Lebanon. Environ. Monit. Assess. DOI: 10. 1007/s 10661-010-1333-7, springer.

18. Khaniki, G. R. J., Zarei, A. Kamkar, A., Fazlzadehdavil, M., Ghaderpoori, M. and Zarei, A. (2010). Bacteriological Evaluation of Bottled Water from Domestic Brands in Tehran Markets, Iran. World Applied Sciences Journal, 8 (3): 274278.

19. Zeenat, A., Hatha, A.A., Viola, L. and Vipra, K. (2009). Bacteriological quality and risk assessment of the imported and domestic bottled mineral water sold in Fiji. $J$ Water Health, 7(4):642-649.

20. Biadglegne, F., Tessema, B., Kibret, M., Abera, B., Huruy, K., Anagaw, B. and Mulu, A. (2009). Physicochemical and bacteriological quality of bottled drinking water in three sites of Amhara Regional State, Ethiopia. Ethiopian Medical Journal, 47 (4): 277-284.

21. Miranzadeh, M. B., Ehsanifar, M. and Iranshahi, L. (2011). Evaluation of Bacterial Quality and Trace Elements Concentrations in 25 Brands of Iranian Bottled Drinking Water. American-Eurasian J. Agric. \& Environ. Sci., 11 (3): 341-345.

22. Samadi, M.T., Rahmani, A.R. and Sedehi, M. (2009). Evaluation of chemical quality in 17 brands of Iranian Bottled water. J. Res. Health Sci., 9(2): 25-31.
23. Ghaderipoor, M. (2009). Determination of toxic trace element in Bottled Waters Consumption in the of Tehran; $12^{\text {th }}$ National Congress on Environmental Health, Tehran-Iran.

24. Ezeugwunne, I.P., Agbakoba, N.R., Nnamah, N.K. and Anhalu, I.C. (2009). The prevalence Bacteria in Packaged Sachet Water Sold in Nnewi, South East, Nigeria. World Journal of Dairy and Food Science. 4(10):19-21.

25. Muazu, J., Muhammad-Biu, A. and Mohammed, G.T. (2012). Microbial Quality of Packaged Sachet Water Marketed in Maiduguri Metropolis, North Eastern Nigeria. British J. Pharmacol \& Toxicol., 3(1): 33-38.

26. Omalu, I.C.J., Eze, G.C., Olayemi, I.K., Gbesi, S., Adeniran, L.A., Ayanwale, A.V., Mohammed, A.Z. and Chukwuemeka, V. (2010). Contamination of Sachet Water in Nigeria: Assessment and Health Impact. Online Journal of Health and Allied Sciences, 9, Issue 4; 1-3.

27. Ajayi, A.A., Sridhar, M.K.C., Adekunle, L.V. and Oluwande, P.A. (2008). Quality of Packaged Waters Sold in Ibadan, Nigeria, Afr. J. Biomed.Res. 11(3): 251-258.

28. Kalpana, S., Bagudo, A.I., and Aliero, A. A. (2011). Microbiological analysis of Sachet Drinking Water marketed at two sites in Aliero, Kebbi state, Nigeria. Continental J. Microbiol., 5(1): 29-36.

29. Zmirou, D., Ferley, J. P., Collin, J. F., Charrel, M. and Berlin, J. (1987). A follow up study of gastrointestinal diseases related to bacteriological substandard drinking water. American J. Pub. Hlth., 77: 582-584.

30. Geldreich, E.E. (1996). Sanitary significance of Faecal Coliforms in the Environment Publication No. WP-20-3. Federal Water Pollution Control Administration, Cincinnati, Ohio. 122.

31. Edberg, S.C. (1996). Assessing Health Risk in Drinking Water from Naturally Occuring Microbes. J. Environ. Health., 58(6): 18-24.

32. Sahota, P.P. (2005). Contaminants in Drinking Water. Research Report Punjab Agricultural University, Tribune Publications. Friday July 15, 2005.

33. WHO. (1971). International standards for drinking water. Third ed. World Health Organization, Geneva. 